Jurnal SOSIO DIALEKTIKA 6 (2) (2021)

p-ISSN: 2540.8941 e-ISSN: 2623.2944

e-mail; sosiodialektika@unwahas.ac.id

doi; http://dx.doi.org/10.31942/sd.v6i2.5682
Kompleksitas Penegakkan Hukum

Ekonomi Di Era Reformasi

\title{
Kompleksitas Penegakkan Hukum Ekonomi Di Era Reformasi
}

\author{
Anto Kustanto \\ Dosen Fakultas Hukum Universitas Wahid Hasyim Semarang \\ Email: andanto16@gmail.com
}

\begin{abstract}
Issues that are understood about law relating to the nature of law are made to regulate the order of people's lives so that they are orderly and regularly. Order and regular will not be realized if the rule of law cannot be enforced. The implications of legal regulation in the economic field are various regulatory instruments that affect economic performance, in order to achieve human welfare, both in the short and long term. In this case, the law position is trying to provide a reflection for the creation of an economic justice. Awareness of the need to understand the economic consequences of implementing a rule has actually begun to be discussed, so from this illustration it becomes an argument about the Complexity of Enforcement of Economic Law in the Reformation Era. The aim is to reveal the meaning of a legal action based on law enforcement in the economic field as well as to identify the relationship between variables. Thus, this research produces descriptive data which must be interpreted using qualitative methods. Because this article seeks to provide an explanation of the continuity and integrity of the science and philosophy of law. The reasons that underlie industrial countries and developing countries such as Indonesia, regard the enforcement of economic law as very important, namely program effectiveness, reasons for justice, reasons for credibility, and reasons for efficiency. The phenomenon of economic instability in the reform era is a reflection that management in the economic sector has not fully become our collective commitment, a reductionist and exploitative way of thinking has developed to color the administration of government in the reform era. Enforcement of economic law is actually a preventive or repressive effort in overcoming price volatility and market mechanisms. Law enforcement as a concept that is expected to be one of the foundations for achieving Indonesia's vision in 2030, economic law enforcement occupies an important position to be prioritized because of the vital functions it contains. This concept is an interface between the legal system and the economic system in an effort to realize legal and economic development as a series of stages of nation building. The development of economic law, enforcement in the reform era that its implications for legal institutions and the legal profession. Therefore, it is a challenge for the Indonesian nation in the reform era to find a solution in addition to the challenges of the legal profession, economic actors, and other related professions. In meeting these challenges, an
\end{abstract}


Jurnal SOSIO DIALEKTIKA 6 (2) (2021)

p-ISSN: 2540.8941 e-ISSN: 2623.2944

e-mail; sosiodialektika@unwahas.ac.id

doi; http://dx.doi.org/10.31942/sd.v6i2.5682
Kompleksitas Penegakkan Hukum Ekonomi Di Era Reformasi

attitude that we need to develop together is openness and "intellectual humility", realizing that we will be more successful in making contributions if we work together in an interdisciplinary manner.

Keywords: Law enforcement, law approach to the economy.

\section{A. Pendahuluan}

Sejak "orde reformasi", kita menyaksikan kemajuan yang luar biasa dalam reformasi hukum. ${ }^{1}$ Hukum bukan merupakan persoalan sederhana, perlu cara untuk memandu seseorang agar memperoleh gambaran yang jelas tentang apa hukum itu. Jika, dilihat dari perkembangan aliran pemikiran (hukum), satu aliran akan bergantung pada aliran lainnya sebagai sandaran kritik untuk membangun sebuah kerangka teoritik berikutnya. Sebagai misal, kritik positivime terhadap aliran hukum alam atau kritik kaum modernis terhadap kemapanan modernisme. Itulah dialektika yang tidak dapat ditolak (conditio sine quanon).

Positivisme hukum lahir sebagai sebuah dialektika, atau sebagai tesis atas standar keilmuan sebelumnya, yakni universalitas hukum alam. Demikian pula kaum realis-pragmatik menjadikan kaum positivis sebagai sandaran kritik dan pengembangan teori-teori mereka. Satu pemikiran atau aliran muncul kemudian tidak melenyapkan pemikiran yang telah ada, karena ilmu itu akan bergerak maju (transform). Hal itu disebabkan karena dua alasan $^{2}:$ pertama, hukum adalah objek kajian yang masih harus dikonstruksi (dibangun) sebagaimana kaum konstrukvis menjelaskan, diciptakan menurut istilah positivistik, atau menggunakan istilah bahsa kaum hermenian "ditafsirkan", sehingga cara pandang seseorang tentang hukum akan ditentukan oleh bagaimana orang tersebut mengkonstruksi,

\footnotetext{
${ }^{1}$ Reformasi hukum diartikan sebagai perubahan (sistem) hukum (change or improvement in a law system). Sementara itu Barda Nawawi Arief mengemukakan bahwa reformasi hukum tidak hanya berarti reformasi peraturan perundang-undangan, tetapi mencakup reformasi sistem hukum secara keseluruhan, yaitu reformasi materi/substansi, struktur dan budaya hukum. Bahkan terkait dengan keseluruhan sistem politik dan sistem sosial (termasuk sistem ekonomi). (Barda Nawawi Arief (I), Masalah Penegakkan Hukum dan Kebijakan Penanggulangan Kejahatan, Citra Aditya Bakti, Bandung, 2001, hal.1)

${ }^{2}$ Prof. Dr.H.R. Otje Salman -Anton F.Susanto, Teori Hukum : Mengingat, Mengumpulkan dan Membuka Kembali, PT. Reflika Aditama, 2013, hal. 7
} 
Jurnal SOSIO DIALEKTIKA 6 (2) (2021)

p-ISSN: 2540.8941 e-ISSN: 2623.2944

e-mail; sosiodialektika@unwahas.ac.id

doi; http://dx.doi.org/10.31942/sd.v6i2.5682
Kompleksitas Penegakkan Hukum Ekonomi Di Era Reformasi

menciptakan, menafsirkan mengenai apa yang disebut hukum itu. Ke dua,satu aliran akan memiliki sudut pandang dengan yang lainnya. Ini merupakan ragam dari kelemahan dan keunggulan masing-masing.

Kondisi ini pada dasarnya memberikan suatu keleluasaan, karena hukum akan menjadi wilayah terbuka yang mungkin saja hasilnya lebih positif, baik dilihat dari sudut filosofis, metodologis juga kepentingan praktis. Apabila keragaman diterima sebagai keindahan, perdebatan sebagaiproses pendewasaan, maka ilmu pengetahuan hukum apaling tidak berada pada tepi garis pencerahan. Gagasan bahwa hukum memiliki keterkaitan dengan budaya masyarakat sebagaimana dikatakan Yahezkel Dror $^{3}$ atau dijelaskan oleh Lawrence M.Friedman ${ }^{4}$, meski bukan yang pertama tetapi pandangan itu telah membuka katup pendekatan hukum yang bersifat dogmatis (murni) menjadi antropos sentris.

Bagi Indonesia, refleksi kefilsafatan tentang hukum itu tidak hanya untuk menjawab sebuah pertanyaan "Apakah hukum dapat disebut sebagai ilmu? Karena terkorelasi dengan pembangunan tatanan hukum nasional yang dicita-citakan dan pengembangan hukum praktis dalam kehidupan sehari-hari. Sebab, objek dari ilmu hukum itu, yakni hukum di masa sekarang menjalani perkembangan oleh suatu kerjasama (interaksi) yang kompleks antara pembentuk perundang-undangan, hakim dan ilmuwan hukum. Isu-isu yang dipahami tentang hukum berkaitan dengan sifat hukum dibuat untuk mengatur tatanan hidup masyarakat agar tertib dan teratur. Ketertiban dan keteraturan tidak akan terwujud apabila aturan hukum tidak dapat ditegakkan. Untuk menjamin dipatuhinya aturan-aturan hukum tersebut, maka ada keharusan-keharusan yang diwujudkan dalam seperangkat norma. Implikasi pengaturan hukum dalam bidang ekonomi

${ }^{3}$ Yehezkel Dror, Law and Social Change, in Joel B. Grosman and Mary H. Grosman, Law and Change in Modern America, Pasific Pilisades, California : Goodyears Publishing Inc,1971. h.36-39. Pandangan Dror tentang hubungan hukum dan budaya ini lebih menitik beratkan kepada hubungan hukum dan perubahan sosial. Hukum merupakan suatu sub sistem di dalam kerangka keseluruhan budaya msyarakat.

${ }^{4}$ Lawrence M. Friedman, Legal System, A Social Science Perspective, Russel Sage Foundations, New York, 1975. Terlihat dari pandangannya tentang sistem hukum yang terdiri dari beberapa komponen dimana salah satu komponen itu disebut dengan komponen kultural. 
Jurnal SOSIO DIALEKTIKA 6 (2) (2021)

p-ISSN: 2540.8941 e-ISSN: 2623.2944

e-mail; sosiodialektika@unwahas.ac.id

doi; http://dx.doi.org/10.31942/sd.v6i2.5682
Kompleksitas Penegakkan Hukum Ekonomi Di Era Reformasi

adalah berbagai perangkat regulasi yang mempengaruhi kinerja ekonomi, untuk mencapai kesejahteraan umat manusia baik jangka pendek atau jangka panjang. Dalam hal ini, posisi hukum adalah berusaha memberikan refleksi bagi terciptanya sebuah keadilan ekonomi, karena keadilan adalah kebajikan utama dalam institusi sosial - sebagaimana kebenaran dalam sistim pemikiran. Atas dasar itu, keadilan menolak jika lenyapnya kebebasan bagi sejumlah orang dapat dibenarkan oleh hal lebih besar yang didapatkan orang lain.

Ilmu ekonomi adalah mempelajari bagaimana agar pemakaian faktorfaktor produksi tersedia seefisien mungkin, dalam memenuhi permintaan masyarakat yang tidak terbatas atas barang dan jasa. Problem utamanya, karena sementara kebutuhan dan keinginan manusia tidak terbatas, padahal sumber daya alam, tenaga kerja, barang dan jasa persediannya terbatas. Sumber daya relatif langka terhadap permintaan yang dibutuhkan untuk memenuhi kepuasan manusia. Akibat kelangkaan itu, manusia mesti melakukan pilihan rasional untuk mengalokasikan sumber daya terbatas yang ada.Ilmu ekonomi memiliki dimensi mikroekonomi dan amkroekonomi. Mikroekonomi berkepentingan dengan efisiensi penyediaan produk tertentu yang melibatkan konsumen dan perusahaan-perusahaan dengan interaksi pasar, sedangkan makroekonomi berkepentingan dengan efisiensi penggunaan seluruh sumber daya dalam perekonomian, khususnya pada pencapaian kesempatan kerja penuh (full employment) dari sumber daya yang tersedia serta pertumbuhan keluaran (out put) sepanjang waktu. ${ }^{5}$

Sesungguhnya, isu utama dalam ilmu ekonomi adalah bagaimana cara memaksimalkan kesejahteraan masyarakat (wealth maximization) dan itu bisa tercapai jika mekanisme pasar dapat berlangsung secara bebas tanpa rintangan atau intervensi. Terkadang campur tangan pemerintah tidak dipoerlukan, karena keyakinan adanya tangan tak terlihat. Kedekatan antara

${ }^{5}$ Christhoper Pass \& Bryan Lowers, 1994, Collins Dictionary of Economics, Harpers Collins Publisher, UK, Edisi Indonesia, Kamus Lengkap Ekonomi, Edisi Ke dua , Erlangga, Jakarta, hlm. 182 
Jurnal SOSIO DIALEKTIKA 6 (2) (2021)

p-ISSN: 2540.8941 e-ISSN: 2623.2944

e-mail; sosiodialektika@unwahas.ac.id

doi; http://dx.doi.org/10.31942/sd.v6i2.5682
Kompleksitas Penegakkan Hukum Ekonomi Di Era Reformasi

disiplin ilmu hukum dan ilmu ekonomi misalnya, ditunjukkan oleh fakta bahwa dalam ilmu ekonomi istilah "hukum" digunakan untuk menjelaskan suatu keteraturan empirik yang sudah baku seperti : hukum permintaan dan penawaran (law of demand and supply), hukum hasil lebih yang semakin berkurang (law of deminishing return) yang dirumuskan oleh Turgot, hukum Say (Say's law : production creates its own demand) ${ }^{6}$ Eksistensi hukum diakui manusia karena sifat mengaturnya, sekarang dihadapkan dengan isu-isu ekonomi tentang kebebasan pasar, yang tidak boleh diganggu. Jika hukum berbicara tentang pengaturan, maka ekonomi justru menghendaki terwujudnya kebebasan. Kata "pengaturan" dalam hukum dihadapkan pada kata "kebebasan" dalam ekonomi secara harafiah memiliki konotasi dan makna yang berseberangan. Ke dua kata tersebut dapat mewakili pandangan bagaimana dua disiplin ilmu yang memiliki paradigma berbada karena kedudukan yang bertolak-belakng tersebut, justru ternyata memiliki titik singgung yang memacu para ilmuwan hukum dan ilmuwan ekonomi untuk memahami serta mengakrabkan lebih dalam lagi.

Kesadaran akan perlunya memahami akibat ekonomi terhadap penerapan suatu aturan sebenarnya telah mulai didiskusikan pada paruh pertama abad 18, saat Adam Smith mulai mengangkat dalam diskusinya tentang efek penerapan aturan hukum yang berpihak pada kaum merkantilis saat itu, maka dari ilustrasi di atas menjadikan sebuah argumentasi tentang Kompleksitas Penegakkan Hukum Ekonomi di Era Reformasi. Tujuannya, untuk mengungkapkan makna sebuah tindakan hukum yang berlandaskan pada penegakkan hukum di bidang ekonomi di samping untuk mengidentifikasi hubungan antar variabel seperti misalnya hubungan antara ekonomi dan lingkungan serta menjelaskan mengapa hubungan ini ada di para pelaku usaha. Sehingga, riset ini menghasilkan data deskriptif yang kemudian harus diinterpretasikan dengan menggunakan metode kualitatif.

6 Sumitro Djojohadikusumo merumuskan istilah "hukum-hukum ekonomi"sebagai Fenomena ekonomi dalam kehidupan masyarakat yang dipengaruhi dan digerakkan oleh kekuatankekuatan yang terkandung dalam masyarakat sendiri”, Yayasan Obor Indonesia, Jakarta, 1991, hlm.29 
Jurnal SOSIO DIALEKTIKA 6 (2) (2021)

p-ISSN: 2540.8941 e-ISSN: 2623.2944

e-mail; sosiodialektika@unwahas.ac.id

doi; http://dx.doi.org/10.31942/sd.v6i2.5682
Kompleksitas Penegakkan Hukum

Ekonomi Di Era Reformasi

\section{B. Metode Penelitian}

Ketika kompleksitas penegakkan hukum ekonomi di era reformasi semakin fenomenal dalam tataran praktis sehingga menjadikan kesulitan untuk menjelaskan penerapannya dalam perspektif sosiologis. Kerangka metodologis yang dipilih dalam artikel tidak dapat dilepaskan dari metode pendekatan kualitatif. Sebab, artikel ini berusaha memberikan penjelasan terhadap kontinuitas dan integritas dari ilmu dan filosofi hukum. Penelitian kualitatif berjenis penelitian terapan ini hasilnya bukan merupakan ilmu baru, namun lebih condong kepada aplikasi baru yang juga merupakan penerapan dari ilmu hukum murni, karena penelitian hukum dilakukan untuk mencari pemecahan atas isu hukum yang timbul, maka penelitian hukum adalah suatu penelitian didalam kerangka know-how. Hasil yang dicapai memberikan preskripsi mengenai apa yang seyogyanya atas isu yang diajukan. Mengingat penelitian hukum merupakan suatu kegiatan dalam kerangka know-how, isu hukum hanya dapat diidentifikasi oleh ahli hukum dan tidak mungkin oleh ahli yang lain. Sebagaimana diungkapkan oleh Cohen $^{7}$, bahwa hanya mereka yang mempunyai ekspertise dalam menganalisis hukum yang mampu melakukan penelitian hukum.

Ilmu hukum merupakan ilmu yang bersifat perspektif dan terapan, mengingat karakteristik tersebut ilmu hukum selalu berkaitan dengan apa yang seyogyanya atau apa yang seharusnya. Dimana menurut Webster Dictionary, scientific method adalah principles and procedures for the systemathic pursuit of knowledge involving the recognition and formulation of a problem, the collection of data through obeservation and experiment, and the formulation and testing of hypotheses. ${ }^{8}$ Konstruksi pemikiran inilah yang kemudian dapat disebut sebagai logico-hipotetico verificative, dari sini mulai terjadi damarkasi antara apa yang dikatakan ilmiah dan non ilmiah

7 Cohen, Morris L. dan Kent C. Olson, Legal Research, West Publishing Company, ST Paul, MINN, 1999, hal.27

8 Webster Dictionary dalam Peter Mahmud Marzuki, Prof, Dr., Penelitian Hukum, Kencana Perdana Media Group, 2005, hal. 26 
Jurnal SOSIO DIALEKTIKA 6 (2) (2021)

p-ISSN: 2540.8941 e-ISSN: 2623.2944

e-mail; sosiodialektika@unwahas.ac.id

doi; http://dx.doi.org/10.31942/sd.v6i2.5682
Kompleksitas Penegakkan Hukum Ekonomi Di Era Reformasi

yang tidak dapat dibuktikan secara empirik, sehingga dikatakan tidak bersifat ilmiah.

\section{Pembahasan}

Pada hakekatnya hukum mengandung ide atau konsep, dengan demikian boleh digolongkan kepada sesuatu yang abstrak - ke dalam kelompok abstrak ini termasuk ide tentang keadilan, kepastian hukum dan kemanfaatan sosial. Apabila kita berbicara mengenai penegakkan hukum, maka pada hakekatnya kita berbicara mengenai penegakkan ide-ide atau konsep yang notabene adalah abstrak itu. Dirumuskan secara lain, maka penegakkan hukum merupakan suatu usaha untuk mewujudkan ide-ide tersebut menjadi kenyataan. Padangan bahwa sistem hukum itu sebagai suatu yang otonom dan netral lazim dalam gambaran kaum positivis atau formalis, yang juga sentral dalam tradisi civil law system. Hal itu sebagai konsekuensi dari anggapan kaum positivis atau formalis bahwa hukum merupakan "special system of reasoning" yang dikarakterisasi melalui kualitas koherensi atau sebagai seperangkat prinsip yang direncanakan menjadi suatu sistem logika yang artifisial. Jadi, perbedaan konsepsional diantara sistem hukum jauh lebih mendalam daripada sekedar prosedur dan presentasi argumen atau metode-metode konstruksi. Sehingga, "harmonisasi" dan "konvergensi" bukan masalah sederhana untuk diusahakan dengan menganggap mudah. Di lain pihak, optimisme pada usaha-usaha dalam melakukan penegakkan hukum ekonomi bagaimanapun juga bukan sesuatu yang tanpa biaya atau harga, lebih-lebih ketika ditolak oleh host system, dapat menyebabkan kerugian substansial. Demikian juga, terjadinya penegakkan hukum tidak terbatas atau dibatasi pada sistem hukum yang memiliki pertalian atau hubungan historis belaka, tetapi sangat bergantung pada kehendak politik atau bangsa yang mentransfer hukum dalam konteks pembangunan hukum di negerinya, baik melalui prosesproses yang top down maupun bottom up. 
Jurnal SOSIO DIALEKTIKA 6 (2) (2021)

p-ISSN: 2540.8941 e-ISSN: 2623.2944

e-mail; sosiodialektika@unwahas.ac.id

doi; http://dx.doi.org/10.31942/sd.v6i2.5682
Kompleksitas Penegakkan Hukum Ekonomi Di Era Reformasi

Realitas ini menunjukkan bahwa tidak semua sistem hukum memiliki kaitan historis, di samping memiliki budaya hukum yang berbeda pula. Sehingga, penegakkan hukum ekonomi lebih dari sekedar menghadapi persoalan adaptasi, tetapi juga kemungkinan penolakan yang hal ini tidak cukup hanya diberikan penjelasan. Sebab, penegakkan hukum di bidang ekonomi hanya terbatas pada sistem hukum yang memiliki pertalian dimana dapat meruntuhkan niat dari penegakkan hukum itu. Penegakkan hukum ekonomi sesungguhnya bukan satu-satunya cara atau alat penataan (compliance tool). Penataan dapat ditempuh melalui cara-cara lain seperti instrumen lingkungan, public pressure yang efektif, company rating (mengumumkan perusahaan yang berprestasi dalam pengelolaan lingkungan dan yang melakukan pelanggaran) disamping melakukan pendekatan melalui mekanisme negosiasi dan mediasi serta perizinan. Alasan yang mendasari negara-negara industri dan negara berkembang seperti halnya Indonesia, menganggap penegakkan hukum ekonomi sebagai hal yang sangat penting, yaitu ${ }^{9}$ :

- Efektifitas Program, Program yang menjadi tumpuan dari diundangkannya peraturan perundang-undangan dibidang ekonomi yaitu melindungi setiap orang atas ekonomi yang baik dan sehat serta perlindungan penstabilan harga terkait dengan daya beli masyarakat akan berjalan efektif apabila dilaksanakan secara taat asas melalui penegakkan hukum.

- Alasan Keadilan, Sikap konsisten dan tegas terhadap pihak yang tingkat ketaatannya rendah dimana sangat penting untuk mencegah pihak-pihak tersebut mengambil keuntungan dari pelanggaran yang dilakukan. Pakan Disisi lain, pihak yang tingkat ketaatannya tinggi justru mengalami kerugian karena adanya perlakuan diskriminatif. Sikap yang tidak konsisten dan tegas terhadap pihak pelanggar menimbulkan ketidakadilan.

\footnotetext{
${ }^{9}$ Dr. Johnny Ibrahim, SH,Mhum, “Pendekatan Ekonomi terhadap Hukum”, PMN Itspress,
} hal. 125 
Jurnal SOSIO DIALEKTIKA 6 (2) (2021)

p-ISSN: 2540.8941 e-ISSN: 2623.2944

e-mail; sosiodialektika@unwahas.ac.id

doi; http://dx.doi.org/10.31942/sd.v6i2.5682
Kompleksitas Penegakkan Hukum Ekonomi Di Era Reformasi

- Alasan Kredibilitas, Kredibilitas institusi pemerintah akan terjaga apabila hukum yang diundangkan dilaksanakan secara konsisten dan sungguh-sungguh.

- Alasan Efisiensi, Penegakkan hukum ekonomi yang konsisten merupakan langkah strategis dan efisien. Timbulnya pelanggaran peraturan perundang-undangan mengakibatkan ke tidak stabilan harga menjadi beban masyarakat, negara serta industri itu sendiri.

Fenomena ketidakstabilan ekonomi di era reformasi bukanlah hal baru. Itu merupakan sebuah cermin bahwa pengelolaan di sektor ekonomi belum sepenuhnya menjadi komitmen kita bersama, cara berfikir yang reduksionis dan eksploitatif telah berkembang mewarnai penyelenggaraan pemerintah di era reformasi. Pandangan penyelenggara pemerintah : Eksekutif dan Legeslatif tentang bagaimana melihat keberadaan hukum ekonomi dan sumber daya masyarakat belum banyak berubah. Ekonomi dan sumber daya masyarakat dilihat sebagai sesuatu yang terpisah sehingga bisa dieksploitasi untuk kepentingan pajak. Sumber daya masyarakat tidak lebih dari derivatif kebijakan ekonomi, sumber daya masyarakat hanyalah bagian dari komoditas ekonomi untuk mendapatkan keuntungan. Belum banyak yang melihat bahwa sumber daya masyarakat dalam ekonomi memiliki kapasitas saling mendukung kegiatan-kegiatan yang berlangsung dibidang lainnya, seperti bidang lingkungan hidup.

Pada bab sebelumnya telah sedikit diuraikan bahwa penegakkan hukum ekonomi sebetulnya adalah upaya preventif maupun represif dalam menanggulangi ketidakstabilan harga dan mekanisme pasar. Upaya preventif berarti pengawasan aktif yang dilakukan terhadap kepatuhan atas peraturan tanpa kejadian langsung yang menyangkut kejadian konkrit, upaya preventif dilakukan dengan pemantauan dan penggunaan kewenangan yang bersifat pengawasan. Sedangkan, upaya represif dilaksanakan dalam hal ada perbuatan melanggar peraturan dan upaya ini bertujuan untuk mengakhiri perbuatan terlarang tersebut. Namun, upaya preventif maupun represif dalam penegakkan hukum akan efektif apabila penegakkan hukum 
Jurnal SOSIO DIALEKTIKA 6 (2) (2021)

p-ISSN: 2540.8941 e-ISSN: 2623.2944

e-mail; sosiodialektika@unwahas.ac.id
Kompleksitas Penegakkan Hukum Ekonomi Di Era Reformasi doi; http://dx.doi.org/10.31942/sd.v6i2.5682

(ekonomi) tersebut benar-benar didukung oleh substansi hukum, struktur penegakkan hukum, serta kultur hukum yang memadai. Masalahnya, apakah ketiga komponen tersebut di era reformasi telah benar-benar dapat diandalkan untuk mengefektifkan penegakkan hukum ekonomi.

Persoalan penegakkan hukum ekonomi tidak sekedar penyiapan substansi hukum dan kelembagaan yang memadai, tetapi juga menyangkut kultur (dalam hal ini kultur hukum). Persoalan pertama, apakah pemerintah, masyarakat dan pelaku usaha (ekonomi) benar-benar mempunyai kesadaran untuk mengedepankan perihal Undang-Undang yang mengatur tentang kegiatan ekonomi selalu menjadi bahan pertimbangan setiap tindakan yang akan diputuskan oleh pemerintah maupun dunia usaha. Persoalan kedua, berbicara masalah penegakkan hukum ekonomi akan lebih memiliki greget kalau melihatnya bukan hanya dari kacamata keharusan-keharusan hukum. Karena, ketentuan hukum sering tinggal hanya ketentuan saja. Kita sering melihatnya dari karakteristik kasus-kasus ekonomi yang terjadi di lapangan, bahwa kasus-kasus ekonomi umumnya merupakan perkara yang menghadapkan pihak industri dan atau pemerintah (sebagai pihak yang kuat) dengan masyarakat selaku korban (berada pada pihak yang lemah). Apabila kasunya harus menjadi kasus hukum yang memerlukan proses litigasi, maka hasil akhirnya akan menempatkan satu pihak di posisi menang dan satu pihak lain di posisi kalah. Penentuan siapa kalah dan siapa menang dalam proses litigasi yang formal tentu didasarkan siapa yang dapat memberikan bukti paling meyakinkan, karena bagi kepentingan litigasi pembuktian adalah penting. Pada umumnya, pihak yang kuatlah (baik industri dan atau pemerintah) yang dapat memberikan bukti secara meyakinkan daripada pihak korban. Sebab, pihak yang kuat selalu memiliki akses, sumber daya, dan ekspertasi yang dapat mendukung argumennya. Semisal, dalam kasus-kasus perbankan, asuransi, maupun sektor usaha kecil lainnya.

Penegakkan hukum ekonomi di era reformasi ternyata bukan sekedar menerapkan hukum (peraturan), juga memerlukan dukungan secara 
Jurnal SOSIO DIALEKTIKA 6 (2) (2021)

p-ISSN: 2540.8941 e-ISSN: 2623.2944

e-mail; sosiodialektika@unwahas.ac.id

doi; http://dx.doi.org/10.31942/sd.v6i2.5682
Kompleksitas Penegakkan Hukum Ekonomi Di Era Reformasi

akumulatif dan sinergis antara substansi peraturan, kelembagaan yang menegakkan, serta kultur hukum yang mendukung. Penegakkan hukum ekonomi menjadi rumit karena persoalan masyarakat di era tatanan sosial sekarang ini terkait dengan masalah ekonomi, sosial, dan kepentingan negara. Di Indonesia kesiapan ketiga hal tersebut di atas bukanlah hal yang bisa diwujudkan secara cepat sehingga masalah ekonomi di Indonesia terkesan berlarut-larut penyelesaiannya. Banyak hal yang harus dilakukan serentak apabila ada perbaikan ekonomi di masa mendatang demi keberlanjutan kehidupan. Mencermati yang terjadi di negara lain, nampak bahwa pelaksanaan semua kegiatan ekonomi yang menyangkut : produksi, distribusi, dan pemasaran barang serta jasa maupun pelaksanaan hubungan timbal balik dunia usaha nasional dengan mitra usahanya itu harus didasarkan pada tatanan atau sistem yang berjalan, yang lebih lanjut dilandasi aturan perundang-undangan. Hubungan ini menunjukkan keterkaitan aspek hukum dengan ekonomi baik dalam kegiatan investasi, produksi, distribusi, pemasaran maupun hubungan antar negara secara bilateral, regional, dan multilateral.

Kita sama-sama memaklumi bahwa ada kegiatan ekonomi/usaha yang tumbuh di tahun-tahun terakhir ini dan belum memperoleh pengaturan dengan cepat, semisal usaha mikro kecil menengah (UMKM). Hal ini terjadi antara lain karena kompleksnya masalah yang timbul akibat globalisasi perdagangan antar negara yang berdampak luas terhadap perdagangan dalam negeri, serta terhadap hukum yang mengatur bidang perdagangan atau ketentuan-ketentuan hukum yang terdapat dalam Kitab UndangUndang Hukum Dagang (KUHD). Namun, kiranya perlu juga disadari bahwa menyusun peraturan-peraturan bidang ekonomi untuk mencapai penegakkan hukumnya perlu pemahaman secara baik mengenai materi yang diatur.

Sementara itu, perkembangan aktivitas perdagangan dunia berpacu dengan cepatnya perkembangan teknologi. Agar tidak jauh tertinggal dan supaya bisa menangkal dampak negatif dari perkembangan perekonomian 
Jurnal SOSIO DIALEKTIKA 6 (2) (2021)

p-ISSN: 2540.8941 e-ISSN: 2623.2944

e-mail; sosiodialektika@unwahas.ac.id

doi; http://dx.doi.org/10.31942/sd.v6i2.5682
Kompleksitas Penegakkan Hukum Ekonomi Di Era Reformasi

serta perdagangan dunia dibutuhkan aspek penegakkan hukum yang aktif ambil bagian dalam setiap kegiatan menyangkut perkembangan bidang ekonomi. Kebutuhan akan adanya penegakkan hukum bisa dirasakan terutama dalam menghadapi pesaing-pesaing usaha luar negeri didalam bernegosiasi atau berkompetisi, maupun dalam mematahkan argumentasi yang didasarkan pada ketentuan-ketentuan General Agreement on Tariffs and Trade (GATT). Sesungguhnya, telah banyak peraturan perundangundangan yang diterbitkan di bidang ekonomi di tahun terakhir ini, namun harus diperhatikan sisi aspek penegakkan hukumnya. Satu hal yang penting bahwa didalam penyusunan suatu perangkat hukum, hendaknya dilibatkan atau diperhatikan pula pendapat pihak-pihak yang selama ini terlibat langsung atau yang melakukan praktek-praktek perdagangan. Ini disebabkan karena kondisi di lapangan sering kali jauh berbeda dengan aturan-aturan yang dibuat.

Penegakkan hukum sebagai sebuah konsep yang diharapkan menjadi salah satu pondasi pencapaian visi Indonesia di 2030, penegakkan hukum ekonomi menempati posisi penting untuk diprioritaskan karena fungsi vital yang dikandungnya. Setelah mengurai ke empat aspek yang secara langsung memengaruhi konsep penegakkan hukum ekonomi, dapat diketahui bahwa konsep penegakkan hukum ekonomi merupakan titik temu antara sistem hukum, dan sistem ekonomi dalam upaya mewujudkan pembangunan hukum dan ekonomi sebagai rangkaian tahapan pembangunan bangsa. Salah satu diagnosa penyebab berkepanjangannya krisis ekonomi Indonesia antara lain, karena terjadinya moral hazard di berbagai sektor ekonomi dan politik. Permasalahan moral hazard sudah cukup luas dan mendalam. Dalam skala yang luas, faktor moral dan etika harus dimasukkan sebagai variabel ekonomi yang penting, khususnya dalam pola tingkah laku berekonomi dan berbisnis.

Faktor yang utama bagi hukum untuk dapat berperan dalam pembangunan ekonomi adalah apakah hukum mampu menciptakan (stability), predictability, dan "enforcement". Dua hal yang pertama adalah 
Jurnal SOSIO DIALEKTIKA 6 (2) (2021)

p-ISSN: 2540.8941 e-ISSN: 2623.2944

e-mail; sosiodialektika@unwahas.ac.id

doi; http://dx.doi.org/10.31942/sd.v6i2.5682
Kompleksitas Penegakkan Hukum Ekonomi Di Era Reformasi

prasyarat bagi sistem ekonomi apa saja untuk berfungsi. Termasuk dalam fungsi stabilitas adalah potensi hukum guna menyeimbangkan dan mengakomodasi kepentingan-kepentingan yang saling bersaing. Kebutuhan fungsi hukum untuk dapat meramalkan akibat dari suatu langkah-langkah yang diambil khususnya penting bagi negeri yang sebagian besar rakyatnya untuk kali pertama memasuki hubungan-hubungan ekonomi melampaui lingkungan sosial yang tradisional. Aspek penegakkan seperti perlakuan yang sama dan standar pola tingkah laku pemerintah adalah perlu untuk menjaga mekanisme pasar dan mencegah birokrasi yang berlebihan.

\section{Simpulan}

Setelah membahas proses perkembangan penegakkan hukum ekonomi di era reformasi menunjukkan implikasinya terhadap pranata hukum, dan profesi hukum, yang secara umum dapat dikemukakan beberapa catatan, yaitu perkembangan eksternal ditandai dengan berbagai perubahan yang mendorong terjadinya proses penegakkan hukum sebagai suatu kecenderungan yang terlihat menonjol karena hubungan ekonomi, moneter, dan perdagangan antar bangsa yang ditandai oleh kurangnya kepastian hukum serta ketatnya persaingan. Karena itu, merupakan tantangan bagi bangsa Indonesia di era reformasi untuk mencari penyelesaiannya di samping tantangan profesi hukum, pelaku ekonomi, dan profesi lain yang terkait. Dalam menghadapi tantangan itu suatu sikap yang perlu kita kembangkan bersama adalah keterbukaan dan "intellectual humility", dengan menyadari bahwa kita akan lebih berhasil membuat kontribusi bila bekerjasama secara interdisiplin. 
Jurnal SOSIO DIALEKTIKA 6 (2) (2021)

p-ISSN: 2540.8941 e-ISSN: 2623.2944

e-mail; sosiodialektika@unwahas.ac.id
Kompleksitas Penegakkan Hukum Ekonomi Di Era Reformasi

\section{DAFTAR PUSTAKA}

Pass, Christhoper \& Lowers, Bryan 1994, Collins Dictionary of Economics, Harpers Collins, Publisher, UK, Edisi Indonesia

Kamus Lengkap Ekonomi, Edisi Ke dua, Jakarta, Penerbit Erlangga.

Grosman, Joel B. and Mary H.Grosman, 1971, Law and Change in Modern America, Pasific Pilisades, California : Goodyears Publishing Inc.

Ibrahim, Johnny, Pendekatan Ekonomi terhadap Hukum, PMN Itspress.

Friedman, Lawrence M., 1975, Legal System, A Social Science Perspective, New York, Russel Sage Foundations.

Marzuki, Peter Mahmud 2005, Penelitian Hukum, Kencana Perdana Media Group.

Djojohadikusumo,Sumitro 1991, Perkembangan Pemikiran Ekonomi, Jakarta, Yayasan Obor Indonesia. 